\title{
European Journal of Turkish Studies
}

Social Sciences on Contemporary Turkey

15 | 2012

Les fabriques coercitives du politique

\section{Hukukçu Otobiyografileri ile 12 Eylül Yasallığının Dinamiklerini Düşünmek}

In-depth Analysis of the September 12 Legality dynamics through Jurists

Autobiographies

Dicle Koğacıoğlu

\section{(2) OpenEdition \\ Journals}

Electronic version

URL: http://journals.openedition.org/ejts/4733

DOI: $10.4000 /$ ejts.4733

ISSN: $1773-0546$

Publisher

EJTS

Electronic reference

Dicle Koğacıoğlu, « Hukukçu Otobiyografileri ile 12 Eylül Yasallığının Dinamiklerini Düşünmek »,

European Journal of Turkish Studies [Yayında], 15 | 2012, Son güncelleme 20 juin 2013, Erişim tarihi 16 février 2020. URL : http://journals.openedition.org/ejts/4733 ; DOI : 10.4000/ejts.4733

This text was automatically generated on 16 février 2020 .

(c) Some rights reserved / Creative Commons license 


\section{Hukukçu Otobiyografileri ile 12 Eylül Yasallığının Dinamiklerini Düşünmek}

In-depth Analysis of the September 12 Legality dynamics through Jurists Autobiographies

Dicle Koğacıoğlu

\section{EDITOR'S NOTE}

Dicle Kocacıŏglu, Kasım 2007'de Fransız Anadolu Araştırma merkezi, Fonds d'Analyse des Sociétés Politiques / Réseau d'Analyse des Sociétés Politiques ve Galatasaray Üniversitesi tarafından Istanbul'da düzenlenen 'Toplu Eylemler ve şiddet: Zorlayıcı Yöntemlerin Siyasetin İnşa Sürecine Etkileri' adlı konferansta makalesinin ilk halini sunmuştur. Kocacıoğlu konferans tebliğlerini basıma hazır hale getirirken her ne kadar kendi bölümü üzerinde çalışsa da, son hale getirmemiştir. Bilgi Üniversitesi'nden Seda Kalem ve Pennsylvania Üniversitesi'nden (ABD) Tuğçe Ellialtı, Kocacıŏlu'nun metnine çekidüzen vermek üzere zaman ayırmayı ve araştırma yapmayı içtenlikle kabul etmiştir. Metnin bazı kısımları, Seda Kalem tarafından eklenmiştir. Onları belli etmek için onların sonunda [S.K.] ifadesi konuldu. Bu görevi esirgemeden üstlendikleri için onlara müteşekkiriz.

'Marki özür diledi: "Korkarım Latince bilmiyorum" Abrenuncio cevap verdi: "Bilmenize gerek yok" ve bunu Latince dedi elbette'.

G. G. Marquez, 1995

'Ya büyüklerimiz? Bize yol gösterme sorumluluğu olanlar - Nasil oluyordu da onlar da aynı 
cehalette yaşıyorlard1?'

L. Althusser, 1965

\section{Sorunsal}

1 Darbeler ile hukuk ilişkisini araştıran çoğu araştırma, darbelerin kurup yerleştirdiği olağanüstülük halinin yasallık tecrübesini anayasa gibi en genel nitelikli yasalar çerçevesinde inceler (Parla 1993; Tanör 1986, 2002; Sancar 2008). Bu literatür, 'olağanüstü' ortamlarda geliştirilen genel nitelikli yasalara derinlemesine bakarak, vatandaşların kimliklerinin, devlet ile girebilecekleri ilişkilerin, başka vatandaş ve gruplar ile yaratabilecekleri toplumsallığın adli kurumlar ve pratikler gözünde nasıl kurgulandığını anlamaya çalışır. Bu tahayyülün, düzenleyici etkisinin ötesinde ve onunla beraber, tam da bu toplumsallığın kurulmasındaki etkisinin altını çizen bu çok önemli araştırma alanı, bir yandan da yeni kurulan düzenin ideallerinin eleştirisini yapar. Darbe yasallığı üzerine bir ikinci çalışma alanı ise, bu yasallığın mağdurlarının tanıklıklarını hafıza, şiddet ve öznellik temaları etrafındaki inceleyen çalışmalardır (bkz. İHAD 2009; İyigüngör 2009). Bu çalışmalar, darbe yasallığının normalleştirdiği şiddeti, bu şiddetin o andaki toplumsal ilişki ve kurumlar üzerindeki etkilerine bakarak inceler; ve, bu şiddet ortamında nasıl benlikler yaratıldığına bakarak, yaşananların hatırlanmasının ve temsil edilmesinin zorluklarına değinir. Birinci literatür deyim yerinde ise 'tepede' var olan tahayyül ve tasarımları inceleyerek olaya makro bir perspektifle yaklaşırken, ikinci literatür daha aşağıdan başlayarak mikro pratikler ile darbelerle kurulan yargısal ortam arasındaki ilişkiyi anlamaya çalışır. Bu çalışmada ise, bu iki yaklaşımın arasında kalan, ve aslında biraz da bu iki çalışma alanı tarafından hayalimize bırakılan bir alan olan darbelerin dayandığı ve oluşturduğu adli alan, gündelik hayatta kuruluş ve kullanılış biçimleri üzerinden incelenecektir.

2 şu noktada ilk olarak, darbe yasallığı üzerinden okuyacağımız "olağanüstü yasallık" hali ile nasıl bir kurumsal işleyiş biçiminden bahsedildiğini göz önüne getirebilmek adına, 12 Eylül sıkıyönetim rejiminin ana kurumu olan sıkıyönetim askeri mahkemelerinin bazı özelliklerini hatırlamakta fayda vardır. Öncelikle, bu mahkemelerin hem kanunlar hem de yargılayan otorite bağlamında geçmişe dönük yargılama yapmakta olduklarını belirtmek gerekir. Kanunlar bakımından bu durum, fiiliyatta sanıkların kendilerine isnat edilen suçtan ötürü var olan hukuk kuralları ve yargilama usulleri çerçevesinde değil, sonradan oluşturulmuş bir hukuki çerçeve dahilinde yargılanmaları sonucunu ortaya çıkarmaktaydı. Yargılayan otorite açısından ise, bir suçun ancak işlendiği zaman mevcut olan mahkemeler tarafından yargılanmasını öngören doğal hakim ilkesinin ihlali anlamına gelen bu durum, sanıkların sonradan yapılandırılmış mahkemeler tarafından yargılanmaları sonucunu doğurmaktaydı.

$3 \mathrm{Bu}$ çerçevede, sıkıyönetim mahkemeleri askeri otorite tarafından kurulmakta, bu mahkemelerde görev alan hakim ve savcılar da gene askeri otorite tarafindan atanmakta ve sicilleri de aynı otorite tarafindan tutulmaktaydı. Bu mahkemelerin üzerindeki askeri otoritenin varlığı, çoğu zaman üç kişilik ancak zaman zaman sanık sayısının çokluğuna göre beş kişilik de olabilen mahkeme heyetinin başında hakimlikten gelmeyen bir subayın yer alması ile daha da perçinlenmekte idi. Mahkeme heyetinin başı olan bu subay, mahkeme düzeninden sorumlu olmanın yanı sıra, 
heyetteki diğer hakimler gibi yargılamaya katılmakta ve hatta karar da verebilmekteydi. Heyetin geri kalanını çoğu zaman askeri hakim ve savcılar oluşturmakta idiyse de, ihtiyacın artması durumunda sivil hakim ve savcıların bu mahkemelerde görev alması da mümkün kılınmıştı. Kararları beğenilmeyen hakimlerin yerlerinin değiștirilmesi, hakimlerin emekliliğe zaman zaman henüz süreleri bile dolmadan sevk edilmeleri, ve hatta meslekten ihraç edilmeleri de bu mahkemelerin işleyişinde rastlanılan pratiklerdi ${ }^{1}$. Üstelik bir hakimin tarafsızlığından kuşku duyulması durumunda, taraflara tanınan redd-i hakim hakkının kaldırılmış olması da, siyasal iktidara bağımlı ve askeri düzen çerçevesinde yürütülen bu yargılamaların olağan dışılığına katkıda bulunan bir başka unsurdu. Diğer yandan, anayasanın askıya alınmış olması, 210.000 davada toplam 230.000 kişinin yargılandığı bu mahkemelerin faaliyette olduğu dönemde ${ }^{2}$, hak ihlallerinde başvurulacak bir hukuki yorum kaynağının yokluğu durumunu da doğurmaktaydı. Sıkıyönetim döneminin bir kısmında askeri mahkemelerde verilen üç seneden aşağı cezalar için temyiz hakkının olmaması bu yokluğun en görünür örneklerinden biridir ${ }^{3}$.

4 Sıkıyönetim askeri mahkemelerinin yanı sıra başka kurumlar etrafında da örgütlenen 12 Eylül 1980 darbesinin yasallığı, eleştirel literatürde demokrasi ve insan hakları ihlalleri çerçevesinde betimlenmiştir. Bu çalışmaların hem olgunun önemine hem de bu konuda neler yapılabileceğine ilişkin çok önemli bakış açıları kazandırdıkları bir gerçektir. Ancak, bu ihlallerin toplumsal olarak yaşanma süreçlerinin bir yokluk olarak değil de bir varlık hali içinde tecrübe edilmiş olması, tam da bu ihlalleri bir şeylerin yokluğu -demokrasinin veya insan haklarının- üzerinden düşünmekten ziyade, nasıl olup da olduklarını anlamayı gerektirmektedir. Bu noktadan hareketle, bu yazıda 12 Eylül döneminin yasallığını bir demokratik süreçlerin ve insan haklarının ihlali durumu olarak değil; tam da bu yasallıkta kullanılan ve kurulan olağan dışı adli alanın olağanlaşması durumu üzerinden anlamaya çalışacağım. Toplumbilimsel yöntem ışığında bu olağanlaşmanın parametrelerini, darbe yasallığının gündelik hayatını, bu yasallığa direnmenin koordinatlarını ve direnirken de bir taraftan yeniden kurulan olguları araştıracağım bu çalışmada, 12 Eylül darbesini yaşamış hukukçuların

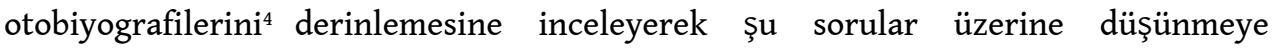
çalışacağım: 12 Eylül'ün yasallı̆̆ı nasıl çalışıyordu? Bu yasallığı gündelik olarak kurmanın ve buna direnmenin yöntemleri neler idi? Bu olağan dışı dönem ile olağan hukuki dönem ve pratikler arasındaki bağlantı ve devamllıklar ne gibi pratik ve tasavvurlar üzerinden kurulmaktadır?

512 Eylül'ün yasallığı nasıl çalışıyordu sorusunun en azından kısmi cevabı, aktif görevleri üzerinden bu yasallığa katkıda bulunan, bu yasallığa direnen ve bu yasallığa seyirci kalan hukukçuların adli alan dahilinde yarattıkları anlam ve pratiklerde yatmaktadır. Burada adli alanı ${ }^{5}$ sadece yazılı kanun metinleri olarak değil, o kanun metinlerinin gündelik hayattaki toplumsal ilişkiler üzerinden uygulanmaları esnasında değişen ve yeniden üretilen bir toplumsal alan olarak görüyorum. Bir diğer deyiş̧le adli alan, yazılı metin olarak anayasa kadar yaş büyütmek için verilen dilekçeyi de kapsarken, mekan olarak da Devlet Güvenlik Mahkemesi (DGM) koridorlarını olduğu kadar icra memurlarının odalarını ya da kalem memuru, vezne ve arzuhalcilerin önündeki kuyrukları da kapsamaktadır. Yargısal alan teriminin daha çok karar ile ilişkilendirilmesinden ötürü, hayatımızın her alanında hukuku tasavvur ederken kurduğumuz bütün belge, pratik ve anlamları, -yani hukukun maddi tarafı ile daha ideal tarafını- beraber düşünebilmek adına adli alan terimini kullanıyorum. Bu 
bağlamda, adli alanda var olmak demek hem kişiler hem kurumlar için bir yandan, hukukun yazı dilini konuşurken dilekleri dilekçelere, dilekçeleri savunmalara, gerekçeli kararlara, ilmühaberlere çevirebilmek ve her an bunu tersine de çevirebilmek gibi bu alanın kendine has özelliklerine hakim olmak anlamına gelirken; diğer yandan, adliye koridorlarında belli şekillerde yürüyüp, diğer hukukçulara, adliye çalışanlarına ve vatandaşlara toplumsal olarak yaratılan ve öğrenilip yeniden üretilen şekillerde davranmayı da kapsar.

Adli alanın yazı ile dünya kurmak veya olan ile olması gerekeni birleștirmek gibi kendine has özellikleri onu bürokratik alan ya da artistik alan gibi diğer toplumsal alanlardan ayırmaktadır. Alanın ayırdedici bu özellikleri, gündelik hayatın maddi pratiklerinde aktörlerin yaratıcılığı ile kurulmakta; ve bu yaratıcılık da aslında bu adliliğin her gün biraz değiștirilip biraz yeniden yapılması anlamına gelmektedir. Bir diğer deyişle, hukukilik veya adlilik bu alanın aktörleri tarafından her gün biraz değiştirilip biraz yeniden kurulan pratikleri ve tasavvurları içermektedir. Tam da bu nedenle Bourdieu, bu alanı anlamanın hem kendine has özelliklerini anlamaktan hem de bu alanda var olan aktörlerin kendi yaratıcllıklarını bu 'hukuki', 'adli' davranma biçimleri ile nasıl birleştirdiklerini çözümlemekten geçtiğini öne sürmektedir (Bourdieu 1987). Bourdieu'ye göre bu iki boylamın, yani aynı anda hem alana ait özelliklerin aktörleri kuruşunu hem de aktörlerin alana ait özellikleri kuruşunu, incelemek bize bu alandaki toplumbilimsel oluşumları anlamak için imkan tanıyacaktır (Bourdieu 1987).

7 Diğer yandan, de Certeau da gündelik hayattaki bu maddi pratik ve tasavvurları düşünmemizde yararlı olabilecek bir ayrım sunmaktadır. Askeri terminolojiden ödünç aldığ 1 "strateji" ${ }^{6}$ ve "taktik" kavramlarının ayrımında, de Certeau birinci terimi uzun dönemli kurumsal manevralar olarak betimlerken, taktik terimini ise bu kurumsal stratejilerin aktörler tarafından kısa dönemli yaratıcı hareketlerle dönüştürülmesi olarak tanımlar. $\mathrm{Bu}$ çerçevede, mekansal avantajı zamanın kontrolüne dönüştürebilmeleri üzerinden, her zaman olmasa da çoğunlukla, kurumsal olarak üretilebilen stratejilerin, uzun dönemde kendilerini kuran aktörlerin devamlılı̆ıını mümkün kılmak gibi bir amaçları vardır. Zamanın ve insan yaratıcılığının bilinmezliği içinden çıkan taktikler ise, bu tür amaçlar barındırmıyor olsalar da iktidarın mekansal üstünlüğü sayesinde zamanı kontrol ediyor olmasına bir direnç oluşturarak, bu kontrolü yok etmeseler bile dönüştürebilmektedirler (Certeau 1984). Bu noktada darbe yasallığı, tam da kurum ile kurum dışı ve kural ile kural dışı arasındaki ayrımların belirsizleştiği bir alan olması itibarıyla, strateji ve taktik terimleri arasındaki ayrımın ancak bazı durumlarda mümkün olduğu bir alan olarak karşımıza çıkmaktadır. Bu nedenle, tartışmanın geri kalanında, bu ayrımların belirsizleştiği noktalarda, daha genel ve her iki terimi de kapsayan "manevra" terimini kullanacağım.

$8 \mathrm{Bu}$ çerçevede, yazının birinci bölümünde hukukçu otobiyografilerinde darbeye direnmenin koordinatlarını araştırırken, ikinci bölümünde ise darbe yasallığına seyirci kalmanın nasıl anlatıldığını araştıracă̆ım. Direnmeyi ve seyirci kalmayı bir arada tartışmaktaki amacım aralarındaki karşıtlığı sorgulayabilmek. Bu sorgulama, darbe yasallığına direnenler ile seyirci kalanların paylaştıkları tasavvur ve pratikleri araştırarak, bu yasallığı uygulayan ve uygulayarak da aslında yeniden kuran aktörlerin adli alanda birbirleri ile girdikleri ittifak ve rekabetleri anlamayı içeriyor. Bu sorgulama 
ışığında, yazının son kısmında ise Türkiye'de olağanüstü yasallığın tarihsel devamlılığını mercek altına yatıracağım.

\section{Manevra, Strateji ve Taktikler}

9 Yazının bu bölümünde, farklı adli yargı aktörleri arasındaki hareketlerin darbe yasallığının adli alanını nasıl kurdukları üzerine odaklanacağım. Burada altı çizilmesi gereken bir husus, "olağan" yasallıktan farklı olarak, bu alanın kurucu metinlerinin sadece usule ve esasa ilişkin kanunlar ya da olağan genelgeler değil; tam da bu metinlerin çoğunun yerine geçen tüzükler ve kararnameler olduğudur. Diğer yandan, Türkiye'de olağan sayılan hallerde dahi genelge ve kanun hükmünde kararname gibi kaynağını idari otoriteden alan metinlerin sıklıkla kullanıldıkları da göz önünde bulundurulduğu zaman, olağan ve olağanüstü arasındaki karşıtlıklıktan ziyade daha seyrekten yoğuna doğru ilerleyen bir süreklilik (continuum) halinden bahsettiğimizi düşünmek de mümkündür.

10 şu noktada, De Certeau'nun kavramsallaştırmasından hareket ettiğimizde, sanıkların yargılama süreçlerinde adli teşkilatın gerçek ve gerçek olmayan arasında kurduğu ayrım ile oynamalarının, hukukçu otobiyografilerinde ciddi bir kurumsal strateji olarak karşımıza çıktığını görmekteyiz. Bu oynama hali, var olmayan kanıtların yerleştirilmesi veya gerçek olmayan olayların zabıtlarının tutulması gibi değişik biçimler alabilmektedir. Bu kurumsal stratejiye karşı avukatların manevraları ise genel olarak hukukun gerçeklik iddiasına dayandırılmakta, ve avukatlar tarafından bu iddianın usul ile yerleştiğinin özellikle altı çizilmektedir. Bu çerçevede, örneğin usuldeki yanlışlıklar teker teker avukatlar tarafindan rapor edilmekte ve bu gibi durumlarda bir süre sonra başarıya ulaşmak mümkün olabilmektedir. Ancak, başarının uzun zaman sonra gelmesi, aslında kurumsal stratejinin kendisinin tam da sanığı tutuklu tutmak ve böylece de ürkütüp sindirmek için bir manevra olabileceğini de düşündürtmektedir.

11 şüphelinin savcıdan önce polise götürülmesi veya savcının karşısına hiç çıkarılmadan polis tarafından sorguya çekilmesi gibi sorgulama düzeni ve usulü ile ilgili manevralar ise, hukukçu otobiyografilerinde gözlemlenen ikinci bir grup kurumsal stratejiyi oluşturmaktadır. Bu noktada, 12 Eylül döneminde gözaltı sürelerinin onbeş günden otuz güne ve daha sonra da altmış ve hatta doksan güne ${ }^{7}$ çıkarıldı̆̆ı da göz önünde bulundurulduğunda, bu strateji alanının sanığa ne yapılacağını belirsiz kılan ve de gerek kurallar gerekse de makamlar arasında var olan yerleşik hukuki hiyerarşiyi gözetmeyen niteliği öne çıkmaktadır. Bu şekilde, bu strateji alanında sanıkların bedenlerinin tutukluluk mekanlarına kapatılmasıyla, aslında zamandan ve aktörlerin yaratıcılığından doğabilecek karşı hareketlerin önlenmeye çalışıldığını görmek mümkündür. Aynı zamanda, bu stratejiye direnmek için kullanılan taktiklerin de aynı belirsizliği kullandıkları görülmektedir. şu noktada, hukuki hiyerarşilerin bozulması hem kurallar hem de makamlar arasında- kendi başına bir strateji alanı olarak ortaya çıkmamakta; ancak, bahsedilen stratejilere karşı kullanılabilecek bir taktik alanı yaratmaktadır. Bu durumda, adli alanda yer alan bütün aktörlerin aslında bir taraftan emirleri yerine getirirken, bir taraftan da hem etrafta her an değişmekte olan siyasi ortamı, hem yargısal mekanizmaları hem de içinde yer aldıkları profesyonel hiyerarşileri gözetmekte oldukları görülmektedir. Bir avukatın "Koskoca emniyet müdürü bile astlarından korkuyor. Birbirlerine dahi güveni yok bunların" sözleriyle ifade ettiği 
aslında tam da bu durumun göstergesidir. ${ }^{*}$ Açılan bu belirsiz alan, adli aktörler tarafından kurgusal ve gerçek akrabalık veya tanıdıklık ilişkileri ve yazının ilerleyen bölümlerinde bahsi geçen hak sahibi hukukçu vatandaş performansı ile dönüştürülmeye çalışılmaktadır.

Bu belirsiz alanda avukatlar tarafından kullanılan ancak fazla da başarılı olmadığı görülen başka manevralar da mevcuttur. Örneğin, avukatların adli teşkilat tarafından aranan sanığın teslim olmasını ayarlamaları bu tür bir manevradır. Bu manevrada kilit unsur ise, arkadaş ve akrabalık ilişkileri dahilinde sanığın işkence görmeyeceğine dair söz almak ve sanığı bu şekilde görevlilerden birine emanet etmektir. Benzer şekilde, farklı kurumsal stratejilerin karşısında fazla başarılı olamayan manevralar da otobiyografilerde "pek de birşeyin yapılamadığı" durumlar olarak aktarılmaktadır. Örneğin, cezaevinde ya da emniyette kişilerin bulunup bulunmadığı ile ilgili eksik, belirsiz ve çelişkili bilgi verilmesi ya da tutuklunun avukatı ile görüşmek istemediğini öne sürmek ve bu şekilde onu görüşe çıkarmamak da birer kurumsal strateji olarak görülmektedir. Ancak, de Certeau'nun bahsettiği türden bir mekansal baskınlığın tutukluların bedenleri ve zamanları üzerinde bir baskınlığa dönüştürülmesinin gözlemlenebildiği bu durumlarda fazla birşey yapılamadığına dair görüşler otobiyografilerde öne çıkmaktadır.

Diğer yandan, dava dışı olguların kullanılarak, örneğin tutuklunun tek tip elbise giymeyi reddetmesi gibi bir sebeple tutukluyu duruşmaya getirmemek gibi, ihtilafın azaltılması da bir diğer manevradır. Bir avukat bu durumu şöyle aktarır: "(H)akim albay bana: "Bu tek tip elbise işi iyi oldu. İki defa duruşmalardan atıyoruz ve cezayı giydiriyoruz. Başka türlü bu dosyaların sonuçlanması mümkün değil deyince ayağa kalkarak odayı terkettim" (Açan 1998: 198). Avukatlar bu durumu genel olarak usul bakımından sorgularlar. ${ }^{8}$ Burada kurumun önemli bir stratejisi de yürürlükteki kanunların en azından bir kısmı tarafından suç sayılan durumlar söz konusu olduğunda, bu suçlar hakkında şikayet kabul etmemektir. Anlatılarda, bazı sanıkların avukatları aracılığı ile işkence gördüklerine ilişkin ifade vermek istedikleri, ancak bu beyanlarının kabul edilmediği görülmektedir. Sacit Kayasu'nun 1999 ve 2000 yıllarında, birinde vatandaş olarak diğerinde ise savcı olarak bulunduğu darbecilerin yargılanması isteminin işleme konulmaması da, bu olağanlaşmış yasallığa bir başka örnek teşkil eder (2008). Aynı zamanda, böyle kafkaesk bir reddediş ve inkar üzerine kurulan adli alan stratejileri karşısında, sanıkların da bir red taktiğine başvurdukları ve bu şekilde adli mekanizmanın işleyişini durdurmaya çalıştıkları da görülebilmektedir. Örneğin, yukarıda bahsi geçen tutukluların işkence beyanlarının alınmamasına karşılık kimliklerini ibraz etmemeleri, ve bu konuda yakınlarından ve avukatlarından yardım almaları, sürekli olmasa da kısa dönemli bir etki yaratabilen bu tip taktiklerden birisidir. Aslında, olağanüstü durum genelde tek hareketle yapılarak durumları basitleştirdiği ya da homojen olduğu varsayılan bir uygulama olmakla birlikte, yukarıda paylaşılan olaylarda darbe hukukunun gündelik hayatta birçok heterojen uygulama ile belirdiği, ve de bunlara karşı üretilen taktiklerle daha da farklılaşması. Otobiyografilerde oldukça sık olarak davalılar, davalar ve hapishaneler birbirleriyle karşılaştırılır ve bu yersiz olduğu düşünülebilecek farklılaşma betimlenir.

Burada öne çıkan bir husus da hemen hemen bütün manevraların ve karşı manevraların darbe yasallığının usul alanında geçiyor olmasıdır. Hukuki doktrinde usul, sabitliği ve farklı uygulayıcılar arasında aynılığı öngören bir ögedir; zira, hukuku 
hukuk yapan ve hukukun bağımsızlığını kuran asıl öge akılcı usuldur. Artık gücünü dinsel değil dünyevi alandan alan hukuk, bağımsızlığını akılcı ve standartlaşmış şekilde idare edilen usul üzerinden kurar. Bu şekilde resmileștirilen ve sadece hukuk profesyonelleri tarafından işletilen hukuki usulun, bir yandan adli alanı diğer alanlardan ayırırken, bu usule dair bilgiyi ve onu uygulama yeteneğini elinde tutan hukukçuları da diğer aktörlerden ayrıştırdığ tasavvur edilir. Oysa adli alanda hukuki usul üzerinden çatışmalar başlayınca, hukuk sadece eşitlik değil aynı zamanda akılcılık, resmilik ve bağımsızlık ideallerinden de uzaklaşan, ve adalet adı altında yapılan bir seri bürokratik stratejinin ve taktiğin alanı olarak ortaya çıkar. Bir diğer deyişle, hukuki usul keyfileştirilince, adli alanın adlilik özelliği de yara alır.

$\mathrm{Bu}$ çerçevede, yukarıda bahsedilen olaylarda Agamben tarafından ele alınan kural ile uygulamasinin ve kural ile kural koyucunun birbirinden ayrilmaz hale gelmesi durumunu gözlemlemek de mümkündür (Agamben 1998: 171-173). Ancak tam da bu noktada, kural ile uygulanma anının ve uygulayıcısının birleşmesinin de bir kerede ve bütüncül olarak değil; tam da adli alandaki çatışma ve ittifaklar, taktik ve stratejiler ile her defasında yeniden kurularak yapılıyor olması belki de Agamben'e eklenilecek bir nokta olarak karşımıza çıkmaktadır. Otobiyografilere baktı̆̆ımız zaman, örnegin Erdal Eren davasında savunmanın sanığın yaşının henüz on yedi olduğu iddiası üzerinden kemik analizi talebinde bulunmasına mahkemenin verdiği yanıttan da anlaşılabildiği gibi, usul yolu olağanüstü yasallıkta stratejik olarak hem uzatılabilmekte hem de kısaltılabilmektedir. $\mathrm{Bu}$ analiz, olağanlaşmış usulde yer etmiş bir uygulama olmasına rağmen, mahkeme sanığın on sekiz yaşında gösterdiği ve dolayısıyla da öyle olduğu yargısı üzerinden hareket eder. Böylelikle, kemik analizi yapılmadan idama mahkum edilen Erdal Eren gözaltına alındıktan 46 gün sonra asılır.

Diğer yandan, usulun bir taktik olarak direnen tarafça kullanıldığında ise dolambaçlı hale geldiği ve usul yolunun özellikle uzman kurumlar ile ilişki çerçevesinde uzadığı görülmektedir. Örneğin bir işkence davasında, sanıkların işkence gördükleri adli tıp tarafından iki kere belgelenmiş olmasına rağmen, mahkeme bulguların Ankara Sağlık şurası gibi kurumsal varlığı sürekli olmayan başka bir makam tarafından incelenmesini ister. Bu kurumdan gelen ve işkencenin olmadığını beyan eden yazılı açıklama üzerine ise bulgular tekrar adli tıbba gönderilir ve adli tıp da bu sefer işkencenin olmadığına dair rapor verir. ${ }^{9}$ Usulun kısayıp uzaması stratejik bir olay olarak görüldüğünde gözlemlenebilen bir diğer ilginç olay da zaman aşımıdır. Normalde istisnai azlıkta olacağı düşünülebilecek bu olgu, şu anın 'olağan' yasallığında her beş davadan neredeyse birine denk gelmektedir. 0 kadar ki, zaman aşımından düşen davaların oranı beraatten fazladır ${ }^{10}$. Sacit Kayasu'nun darbeci generallerin yargilanması istemiyle sorunlaştırdığı zaman aşımı örneğinde de görülebildiği gibi, usul yolunun uzaması tam da resmi otoritelere karşı olan davaların rutin bir şekilde düşmesine yol açmakta ve de yerleşmiş bir strateji olarak kullanılabilmektedir $(2008)^{11}$.

$\mathrm{Bu}$ strateji ve taktiklere bakarken öne çıkan önemli bir nokta da aslında hukuki usul üzerinden kurulan manevraların, bilgi ve uzmanlık üzerinden oynamalar ile birleşmesi durumunda ortaya çıkan manevra alanının fazlasıyla aşılmaz bir alan olduğudur. Bu noktada, de Certeau'nun öne sürdüğü gibi stratejinin üstünlüğünü mekan üzerinden kuran bir faktör olduğu da göz önünde bulundurulduğu zaman, mekanın baskınlığının hukuki usul ile hem sanıkların bedenleriyle ilgili bilgiyi hem de yargının öğelerinin gerçekliği ile ilgili uzmanlık bilgisini birleştirebiliyor olması üzerinden kurulduğu 
görülebilmektedir. Bir diğer deyişle, tüm bu öğelerin bir çatı altında birleștiği durumlar, aslında direnme taktiklerinin en zor geliştirilebildiği durumlardır.

Bir sonraki bölüme geçmeden önce biraz da direnen tarafın başlattığı manevralara değinmek yerinde olacaktır. En önemli direnme taktiğinin, örneğin savcı hakkında tazminat davası açmak gibi, davaya dava ile karşılık verme olduğu görülmektedir. Ancak bu stratejinin de başarı şansı pek yüksek değildir; zira temel sorunsal yargı düzeninin kendisine dayanır. Örneğin, savaş, seferberlik, sıkıyönetim veya olağanüstü hallerde temel hak ve hürriyetlerin kısmen veya tamamen sinırlandırılmasını düzenleyen Anayasanın 15. maddesi nedeniyle davanın ilerlemesi mümkün olamamaktadır ${ }^{12}$. Aynı zamanda, polislere karşı açılan davalarda da uygulanan ve devlet memurlarının yargılanması önünde çok net engeller koyan 4483 Sayılı "Memurlar ve Diğer Kamu Görevlilerinin Yargılanması Hakkında Kanun" gibi düzenlemeler de bu stratejinin uygulanmasını zora sokmaktadır. Diğer yandan, işkencenin yapıldığı gün emniyette görevli olan bütün polislerin listesini mahkemeye ibraz etmek ise polislere işkence suçlamasıyla dava açıldığı durumlarda ortaya çıkan bir diğer ilginç stratejidir. İşkence iddiasıyla suçlanılan polislerin isimlerinin mahkemeye kurum tarafından ibraz edilen bu listenin dışında bırakılmasıyla, bu polislerin beraat etmeleri ve davanın kapanması sağlanır; zira, mahkemeye ibraz edilen listedeki polislerin gerçekten olayla ilgisi bulunmamaktadır. Otobiyografilerde görülen bir başka taktik de stratejilerin kurulduğu ortamı reddederek değiştirmeye çalışma taktiğidir. Reddi hakim veya reddi mahkeme gayretleri, dosyanın yargılama yetkisinin sıkıyönetim mahkemesine değil adli mahkemeye ait olduğunun savunulmasını içerir. Ancak bu taktik de olağanüstü halin belirsizliğinde usulun çatışma alanı olmasından ve mahkemelerin de aslında tam da stratejilerin anahtar öğeleri olmalarından dolayı fazla etkili olamaz.

Burada görülebilen ve de kural ile uygulama ve uygulayıcı arasındaki ayrımlar kalkınca ortaya çıkan çatışmaları izleyebildiğimiz bu alan, aslında tam da Agamben'in bahsettiği gibi ne hukuki ne de hukuk dışı olan eşikte bir alandır. Burada ana çatışma, yaratılan uygulamalarla birtakım insanların siyasi cemaatin üyesi olma hallerinden çıkartılıp, sadece biyolojik hayata indirgenmeye çalışılması üzerinden dönmektedir. Diğer bir deyişle, Agamben'in kavramsal çerçevesi dahilinde, birtakım insanların hayatları, onlara zarar vermenin ve onları yok etmenin fiilen suç kapsamından çıkarılmasıyla, değersiz kılınarak, kurban edilemez hale getirilir. Üstelik, söz konusu siyasi hayattan biyolojik hayata indirgeniş süreci, Agamben'in varsaydığı gibi bir kerede ve tek taraflı yapılan bir şey de değildir. Daha çok Povinelli'nin açıladığı gibi gündelik hayatta strateji ve taktiklerle yapılan, gene aynı şekillerde de kurulup kurulup bozulan bir şey olarak ortaya çıkmaktadır (Povinelli 2006). Burada görülen o ki, bu stratejiler etrafta bulunabilen bütün mekan, bilgi ve yasal usul gibi ögeleri kullanırken, bu stratejilere direnme taktikleri de aynı şekilde bu öğeleri kullanır.

Son olarak, bu manevralar ve onlara karşı geliştirilen manevralarda sadece usul ögeleri de degil; aynı zamanda duygulanımlar da işin içine dahil olur. Öyle ki, işkenceden yukarıda bahsettiğimiz diğer uygulamalara kadar var olan tüm kurumsal stratejilerin korku uyandırmaya yönelik bir yönü bulunmaktadır. Bu stratejilere karşılık olarak ise gene duygulanım düzeyinde, savunma avukatlarının da iki ana duygulanım ve performans üzerinden taktik geliştirdiği görülebilmektedir. Burada hukukçuların kullandığı bir taktik, neredeyse aşırıya kaçan bir hak sahibi vatandaş performansı 
üzerinden sanıkları tekrar haklara sahip siyasi cemaat üyeleri olarak kurmaya çalışmaktır. Hukukçu anlatılarında bu hak, artık kanuni ya da maddi bir olgu olmaktan çıkıp soyutlanarak idealleştirilir; zira, hakların daha somut ve maddi anlamdaki varlıkları olağanüstü halin belirsizliğinde aslen işlevsizleştirilmiş bir durumdadır. Hukukçuların, hakimlerden savcılara, polislerden gardiyanlara bu yargısal aparatın farklı yerlerinde görev alan tüm kişilere karşı hemen hemen bütün olaylarda kullandıkları bir diğer taktik de utandırmaya çalışma veya utanç duygulanımı uyandırma taktiğidir. Bu taktik dahilinde, sanık veya avukat ile yargı mensubunun üyesi olduğu bir cemaat kurgulanır, ve yargı mensuplarının o anki adli görevlerinin ötesinde bu cemaatin üyesi olarak kendi yaptıklarını gözden geçirmeleri sağlanmaya çalışılır. Avukatın emekli asker ${ }^{13}$ ya da aile babası olması üzerinden kurulan aile ve ordu gibi cemaatlere üyelik, bu taktiğin sık karşılaşılan örnekleri arasında sayılabilir. Aynı zamanda, burada sık sık kurgusal akrabalık bağlarının veya sanığın insanlığının hatırlatılmasıyla kurulmaya çalışılan cemaatler eklendiği zaman, ${ }^{14}$ bu etkinin arttığı da görülmektedir. Anlatılarda öne çıkan bir diğer taktik ise, görevlinin şu anda içinde olduğu durumun geçiciliğinin hatırlatılmasıyla, "asıl olan"ın kurulmaya çalışılmasıdır. Örneğin bir savunma avukatı, hapiste karşılaştığı bir jandarma ile şöyle konuşur: “'Oğlum' dedim, 'Yarın terhis olup gideceksin. şimdi senin giydiğin şu üniformayı giymiş jandarma gelip ensende boza pişirecek"' (Açan 1998: 138) ${ }^{15}$. Son olarak, bazı otobiyografilerde bir iletişim kodu olarak bazılarında ise başlı başına bir cemaat olarak beliren bir başka olgu da erkeklik ya da erkekler dünyası olgusudur ki bu olguya ilerleyen bölümlerde daha fazla değineceğim.

Aslında, tüm bu utanç ve hak sahipliği olgularında görülebilen, usulun ötesinde kültürel anlamlar ile birtakım taktikler yaratma çabasıdır. Bu çerçevede de, tüm bu taktikler dahilinde, utanç duygulanımı ve hak sahipliği performansı üzerinden yapılmaya çalışılanları, biyolojik hayata indirgenmekte olan tutukluları tekrar siyasi cemaatin bir üyesi haline getirme çabaları olarak okumak mümkündür. Ancak bu taktiklerin de nadiren ve son derece kısa ömürlü olarak başarılı olabildiği görülmektedir.

\section{Başka Yerde 12 Eylül}

Darbe yasallığını anlamak, direnmenin koordinatlarını anlamak kadar bu yasallığa katılmanın ve/veya seyirci kalmanın parametrelerini de anlamayı gerektirir. Ne yazık ki okuduğum otobioyografilerde, 12 Eylül yasallığına merkezi olarak katılmış, yapılan kurumsal stratejileri yaratmış kimselerin anlatıları yok. Ancak 12 Eylül'e, ve bazı durumlarda daha önceki darbelere de, farklı derecelerde seyirci kalmış hukukçuların ve hatta hukukçuların yanı sıra başka kişilerin de anlatıları var. Örneğin bazı hukukçular, 1980'den bir iki sene sonra hakimlikten emekli olurken, bazıları ise savcılıktan ayrılıp avukatlı̆̆a başlar. Diğer bazı anlatılarda ise, 12 Eylül hukukçunun statüsünü en azından doğrudan olarak değiştirmeyen oldukça ufak bir olay olarak geçilir.

$\mathrm{Bu}$ bölümde bu tarz hukukçuların anlatılarında 12 Eylül'ün nasıl anlatıldığını inceleyeceğim. Bu noktada ve olağan ile olağanüstünün arasındaki akışkanlı̆̆1 tartışacağım bir sonraki bölümde esasen araştırdığım olgu, direnen hukukçular ile seyirci kalarak bu yasallığı yeniden kuran hukukçuların pratikleri ve tasavvurları 
arasındaki kesişme noktasıdır. Adli alanı her gün yeniden kuran kültürü oluşturan bu kesişmeler sayesinde, bu hukukçular farklı konumda ve/veya farklı fikirde de olsalar birbirlerini anlarlar. şu noktada, adli alan derken özellikle de 12 Eylül sırasında, oldukça küçük ve kültürel olarak da aslında görece homojen bir gruptan bahsettiğimizi de unutmamak gerekir. Yalnızca iki okul -ístanbul ve Ankara Hukuk- mezunu olan 12 Eylül hukukçularının, hakim ve savcı olan çoğunluğu tayin sistemi ile ülkeyi aynı şekilde gezen, aynı maddi pratikler içinde yaşayan ve meslekleri itibarıyla da devamlı olarak birbirlerini ikna etmeye çalışan insanlardır. Bu noktada, bu grubun paylaştı̆̆ ama farklı anlamlandırdığı pratik ve tasavvurları anlamak, darbe yasallığına direnme, katılma ya da seyirci kalmanın ve bunları yaparken de tam da bu yasallığı yeniden üretmenin parametrelerini daha iyi anlamamıza olanak tanıyacaktır.

12 Eylül'ü doğrudan bir direnme anlatısı içinde aktarmayan hukukçuların bazılarında çok ilginç bir şekilde 12 Eylül soyut bir adaletsizlik ile birleştirilir. Bu soyut adaletsizlik kurgusu da kendi yaşadıkları sorunların adı olarak konulur. Örneğin, bir anlatıda kaymakam ve polisler bir kasabada görev yapan savcı hakkında Sıkıyönetim Komutan Yardımcılığına şikayette bulunurlar. Savcı olan yazar buradaki usul ile ilgili problemleri ya da sıkıyönetimin idare ile adalet kurumlarının arasına girmesini eleştirmez. Eleştirisini daha ziyade, kişisel olarak bu kaymakam ve polisler üzerinden kurar ve bu eleştirinin ana duygusal zeminini de 12 Eylül ve adaletsizlik teması oluşturur: "Aradan yıllar geçti. 12 Eylül'ün bıraktığı enkaz hala temizlenmiş değil, dökülen kanların acısı hala dinmiş değil, yıkılan yuvaların dumanı tütmüyor, işkence gören insanların ıstırapları unutulmuyor. Bu kaymakam, şimdi nerelerde, ne iş yapar bilmiyorum. Bu kaymakamın dümen suyunda kapı kulu olup bu raporu tutan (ki bir kısmını çok severdim) polis arkadaşlar şimdi neredeler, ne yapıyorlar, bilmiyorum. Acaba, biraz olsun yürekleri sızlıyor mu? Biraz olsun 12 Eylül'ün ülkeyi acıya, karanlığa yoksulluğa, adaletsizliğe, şiddete va baskıya sürüklediğini anladılar mı?" (Behramoğlu, 2013 [1998]: 210). Bu anlatıda var olan duygusal ton, aslında 12 Eylül'e yakın ya da uzak duran çoğu hukukçunun otobiyografilerini anlamlı kılar; zira, bu duygusallık ile aslında tam da bu darbe yasallığı karşısında alınan farklı tutumların önemi azalır.

$\mathrm{Bu}$ duygusallığın yanı sıra, 12 Eylül'ü tasvir etmenin bir başka yolu da adaletin haklı çıkacağına dair inançtır. Otobiyografilerde, 12 Eylül'de görevine son verilen kişilerin bile aslında bu durumu bir yenilgi olarak yazmadıkları ve sonunda adaletin haklı çıkacağına dair inançlarını korudukları görülür. Bu şekilde de soyut bir adalet ve adaletsizlik kavramları üzerinden birkaç şeyin mümkün kılındığı görülebilir. İlk olarak, hukukçular bu kavramlar etrafında kurdukları anlatılarında, bir taraftan adli alanın geçirdiği olumsuz dönüşümden dem vururken, diğer taraftan özel olarak kimseden bahsetmemiş veya hiçbir usulü mekanizmayı hedef almamış olurlar. Diğer yandan, yakın ilişkide bulunduğu idari ve emniyet personelini eleştiren savcı veya yüksek hakimlikten ayrılıp 80lerde politikaya atılan hakim ${ }^{16}$ örneklerinde gördüğümüz gibi, hukuk ve hukukçuluğu tanımlayan adalet kavramı üzerinden aslında bu hukukçuların kendilerine yeni aktivite alanları yarattıkları da görülebilmektedir. Bu bağlamda, hukukun bir çok usulünün maddi olarak işlevsizleştirildiğinin kabulü, bir noktada bu insanların da gücünü azaltabilecek bir etken iken, adalet gibi soyutlaştırılan bir kavram ile bu alanlar yeniden kurulabilmektedir. Bu noktada, hukuktan bir kurallar bütünü olarak vazgeçmemiş olmak da aslında tam da bu hukuk dışı alanda iktidarı arttırır ve bu aktörlere bir geçmiş ve saygıdeğer bir kimlik kazandırır. 
Son olarak, diğer anlatılarda bir direnme stratejisi olarak kurulan aile, millet, insanlık, erkeklik, askerlik gibi cemaatler, buradaki anlatılarda tam da darbe yasallığına seyirci kalmanın ana terimlerini oluştururlar. Öyle ki, 12 Eylül yasallığına seyirci kalmanın aktarıldığı bu otobiyografilerde, bu tür cemaatler uzun uzun tasvir edilir. Bu konuya da bir sonraki bölümde daha etraflıca değineceğiz.

\section{Normalleşerek Devam Etme [S.K.]}

$\mathrm{Bu}$ makalede ana olgu olarak incelediğim sıkıönetim askeri mahkemeleri aslında 1980 'de değil 1978 'de sıkıyönetim ilan edilmesiyle göreve başlamalarına rağmen, 1980'de sıkıyönetimin yurt çapında ilan edilmesi ile bu mahkemeler bütün yurtta bölgesel bazda çalışmaya başlarlar. Sıkıyönetim sona erdiğinde ise bu mahkemelerde süren davalar 1982 Anayasasında düzenlenerek 1983 yılında kurulan Devlet Güvenlik Mahkemelerine devredilir. DGMlerin 2004'de kapanmaları ile halen devam eden davalar ise bu sefer genişletilmiş Ağır Ceza Mahkemelerine aktarılır. Bu dönemde, Terörle Mücadele Kanunu ile açllan toplumsal ve hukuki alan da olağanüstü yasallığın seyrettiği bir başka yasallık alanı olarak öne çıkar (bkz. Sancar 2008).

şu noktada, sadece 12 Eylül etrafında, hatta sadece kurumsal olarak baktığımızda ortaya çıkan bu durumun, aslında Cumhuriyet tarihinde ciddi bir devamlılık gösterdiği görülebilmektedir. Sıkıyönetim askeri mahkemelerinin öncesinde İstiklal Mahkemeleri, Yassıada mahkemeleri gibi kurumları, Terörle Mücadele Kanunu öncesinde ise Takrir-i Sükun Kanununu görmek mümkündür. Benzer bir şekilde, 12 Eylül sıkıyönetim rejiminin öncesinde de şeyh Sait İsyanı, Menemen Olayı, İkinci Dünya Savaşı sırasında ve sonrasında yedi yıl süren sıkıyönetim dönemi, 6-7 Eylül, 27 Mayıs, Talat Aydemir olayları, 15 -16 Haziran isçi direnişi, 12 Mart 1971'deki iki buçuk yıllık dönem, Kıbrıs harekatı ile getirilen bir yıllık dönem ile 1978 yılında önce 13 ilde ilan edilerek iki yılda 22 ile yayılan sıkıyönetim dönemlerini görüyoruz. Bütün bunlara bir de Türk Ceza Kanununda yer alan ve siyasi addedilen suçları olağanüstü şekillerde yargılayıp cezalandırma hakkı veren maddeleri de eklersek ortaya ilginç bir tablo çıkar ${ }^{17}$. Böyle bakıldığı zaman, olağanüstü yasallığın Türkiye'de hiç de istisnai değil; tam tersi neredeyse olağan yasallık kadar zaman ve yer tutan bir olgu olduğu görülmektedir. Olağanüstünün bu şekilde normalleşmiş, ve hatta tabir yerinde ise adeta olağanlaşmış olması, konunun anlaşılması için tam da adli alanda kullanılan ve kullanılarak da bu alanı her defasında yeniden kuran tasavvur ve pratiklerin anlaşılmasının öneminin altını çizer. Zira, olağan, olağan dışı ve de aradaki geçişler, aslında adli alanın aktörleri tarafından tam da bu kültürel tasavvur ve pratikler üzerinden yaratılır. Bu çerçevede, yazının bu son kısmında, tam da bu olağan dışının olağanlaşmasında önemli olduklarına inandığım ve hakim, savcı ya da avukat, 12 Eylül'den sonra ayrılmış ya da ayrılmamış, direnen ya da seyirci kalan bütün otobiyografilerde ortak olan iki ana olgudan bahsetmek istiyorum.

İlk olgu, kuralın uygulanma anı ve uygulayıcısı ile birleşmesinin, aslında olağan yasallık dönemlerinde de normal kabul edilmesiyle ilgilidir. Örneğin, bir otobiyografide bir tesisin sahiline alınmayan bir savcı yaptıklarını şöyle anlatır: "Takmıştım kafaya. Savcının ne olduğunu öğrenmeleri gerekiyordu. Kendi bölgemde ters yüz edilmiştim. Başladım istihbarata. Çok geçmedi, müdürün altını oymaya çalışan personelden bir ikisine attım kancayı ve beklediğimden de iyi istihbarat aldım: Müdür Beyin hanımı 
çantasında ruhsatsız silah taşıyordu". Anlatının devamında savcı bu silahı yakalatarak tesis müdürüne nasıl zor zamanlar yaşattığını aktarır (Behramoğlu 2013 [1998]: 131-132). Benzer şekilde, olağanüstü yasallık dönemlerinde bu yasallı̆̆ direnenler de kural ile kuralın uygulanmasının birleşmesine karşı durmayabilirler. Bir örnekte, avukat hak sahibi kişi performansı yaparak arkadaşının evini kanunsuz olduğu için aratmaz; ancak, polislerin sahte tutanak hazırlama teklifini de kabul eder. Bu teklifi mümkün kılan ise avukatın polisler ile olan tanışıklığıdır ki bu tanışıklık da polislerin avukatın savunduğu bir sanığa işkence yapmış olmalarına rağmen beraat etmiş olmalarından kaynaklanır. Bu örneklerde görünen o ki, tam da olağan ve olağan dışı yasallığın eşik noktasında şahıslar üzerinden yürüyen bir seri manevra, aslında gerek olağan dönemlerde gerek de olağan dışı dönemlerde gözlenmektedir.

Bütün otobiyografilerde öne çıkan bir ikinci olgu da, erkekler arası toplumsallığın normalliğidir. Hemen hemen hiç kadının olmadığı bu hikayelerin anlatımında, toplumsallığın erkekler arası olduğu adeta söylenmeden kabul edilir ve normalleştirilir. Kadınların tecavüzden zevk aldığını ima eden hikayelerden, genelev kuyruğunda birbirine yol veren erkek hikayelerine kadar bir seri erkek toplumsallı̆̆ 1 anlatısı, hukuki öykülerin yanında normalleşmiş bir şekilde yerlerini alırlar. Örneğin bir arama tasviri sırasında, şöyle bir anekdot paylaşılır: "Gözü arabanın içinde. Baldır bacak görürüm umuduyla olacak herhalde. Araba 34 plakalı ya. Ne yapsın!" (Behramoğlu 2013 [1998]: 185). Bu anlatılarda, erkekler arası yakınlık da düşmanlık da kadınların pahasina kurulur.

Aynı zamanda, bu erkekler arası toplumsallık aile düzeninin koruyucusu ve kurgulayıcısı olarak da görülür. Örneğin 12 Eylül'e seyirci kalma anlatısı olarak görülebilecek bir anlatıda, avukat Perihan Savaş'ı dövmesi üzerine açılan davada İbrahim Tatlıses'in beraat etmesini gururla anlatırken, bu hikayeyi paylaştığı kitabını da ailesine adar. Avukatın otobiyografisine adını veren "gül bahçesi" de aslında aile hayatıdır ve bu şekilde bir taraftan aile hayatı övülürken, diğer taraftan sağ siyasetçilerle olan bağlantılar anlatılır (Kuran 2003). Bu avukatın bütün anlatı boyunca hukuk adına anlattığı sadece üç adet anısı vardır: Bunlardan birinde avukat boşanmakta olan bir çifti nasıl barıştırdığını anlatırken, bir diğerinde ise cinsel olarak tatmin olamadığı için boşanma davası açan bir kadına 'kızım'diye hitap ederek, kendisini toplaması konusunda nasihat verip o evliliği nasıl kurtardığını aktarır. Son anlatıda ise, 12 Eylül davasında solcu bir öğrenciyi öldürmekten sanık sandalyesinde olan bir sağcıyı savunurken, tanıklara 'siz yalan ifade veriyorsunuz' dediği anısını aktarır ki bu anı aslında tam da aile tasavvurunun neler ile birleștiğinin bir göstergesidir (a.g.e $)^{18}$. Bu aile tasavvuru elbette boşlukta duran bir tahayyül de değildir; zira bu tasavvur, gündelik hayatta ailelerden başka kimsenin davalarda müdahil kabul edilmemesi gibi somut kurumsal stratejilerle her defasında yeniden üretilir ve yukarıda da bahsedildiği gibi bu kurumsal stratejilere karşı kurulan kurgusal akrabalık gibi taktiklerle de normalleşir.

$\mathrm{Bu}$ şekilde, aile ve aile düzeni tasavvurları aslında, kadınları dışlayarak, orada olmayan kişiler adına ve orada olmayan kişiler üzerinden, yasallık alanında yapılan oynamaların yanı sıra, kural ile uygulanma anının ve uygulayıcısının birleşmesinin de normal görülmesini sağlar. Bu noktada, aile gibi bir cemaatin varlığı ve bütünlüğü için tüm bu olanların nasıl olduğu, bir diğer deyişle usulü, önemini kaybeder. Aile tasavvuru olağan dışıllğı normalleştirdikçe, aile kurumu ve tasavvurlarına başvurmak olağan ile olağan 
dışının eşiğinde meşru olarak tanınmanın da ön koşulu olarak ortaya çıkar. Sacit Kayasu'nun 12 Eylül darbecilerinin yargılanması için verdiği dilekçenin ilk paragrafında, kendisini evli ve çocuk sahibi, hanım tarafından ailecek asker olan ve ayrıca oğlunu da askeri okula vermeye çalışan biri olarak kurgulaması bu durumun iyi bir örneğidir (2008). Bu tür anlatılarda, aile ve aile üzerinden kurulan bu tasavvurlar, aslında tam da olağan ile olağan dışılık arasında gelgitlerle kurulan toplumsal hayatımızda bildiğimiz ve çağırdığımız bilgilere dönüşürler. Öyle ki, bildiğimiz öteki bilgiye, -kural ile uygulayıcısının ve uygulanma anının birleşebileceği bilgisine-, tam da bu tasavvurlar ve onların üzerinden kurduğumuz ve meşru görülmesini umduğumuz ittifaklarla karşı durmaya çalışırız.

Adli alanda seyreden bir seri manevra ve karşı manevrayı önce tasvir edip, sonra bunları meşrulaştıran tasavvurları anlatmaya çalıştı̆̆ım bu çalışmada, bu tasavvur ve manevraların olağanüstü ile olağan arasındaki bağlantısını, darbe yasallı̆̆ına direnen ve seyirci kalan hukukçuların anlatılarındaki paralellikler üzerinden tartıştım. Burada öne çıkan birkaç nokta var. Bunlardan birincisi, olağan ile olağan dışılık arasındaki durumsal eşik ve zamansal geçişlerde olağan dışıllı̆ın eşit dağıtılmıyor olmasına ilişkindir. Örneğin, mekansal olarak olağanüstü yasallığın hangi şehirlerde ne kadar uygulandı̆̆ına bakmak, bu tür bir yasallığı bazı mekanların çok daha olağanüstü yaşadığını gösterir. Aynı şekilde, kim olarak bu yasallığa dair olduğunuz da fark yaratır; zira, böylesine heterojen bir belirsizlikte, hangi kimlikler ile bu yasallığa dair olduğunuz size uygulanan olağanlığın yahut olağan dışılığın miktarını etkileyebilir. Bu çerçevede, örneğin Doğubeyazıt'ta tecrübe edilen ve/veya bir Ermeni olarak yaşanan olağanüstülük, bir Türk Sünni'nin İzmir'de yaşadıklarından öte olabilir.

Öne çıkan ikinci nokta ise, adli alanın kendisinin de tam bir savaşım alanı olduğudur. $\mathrm{Bu}$ bağlamda, adli alanda direnmeden bahsederken sadece Hrant Dink davasında mahkemenin dışında beklemeyi veya yasa madddelerinin değişimi için kampanya yapmayı anlamak durumunda da değiliz. Yavaş yavaş o mahkeme salonuna girenlerin yaptıklarını veya dediklerini, ya da bir yasa maddesi yürürlükten kalkınca aynı etkinin başka bir maddenin işletilmesiyle nasıl yaratılabileceğini tartışabilir; ve bu şekilde de hukukçuları toplumsal aktör olarak görüp, hukuki aktivizmin ve muhafazakarlığın olanaklarını ve sınırlarını tartışabiliriz. Burada niyetim bütün hukukiliği düz bir toplumsallığa indirgemek de değil. Hem hukukun teknik özelliklerini hem de hukukçuların her zaman adli alanın normları ve hareket sınırları içinde hareket ettiklerini anlayarak, gene de adli alanın içine daha dikkatli bakabilir; ve belki de burada siyasetin ve olağanüstülüğün sıcağında görmediğimiz kadar çok direnme hareketi görebiliriz.

Anlatılarda öne çıkan bir diğer nokta da, Türkiye'deki gayri resmi ilişkilere ilişkindir. $\mathrm{Bu}$ çerçevede, Türkiye'de sık sık geleneksel addedilen ilişkilerin bir türlü modern kurumlar tarafından yok edilemediğinden dem vurulur. Tam da bu nedenle bu çalışmanın, modern ve geleneksel arasında kavramsal olarak karşıtlık kurmanın yersizliğini bir kez daha ortaya koyduğuna inanıyorum. Olağanüstü yasallık, aslında tam da hukuk ile hukuk dışının arasındaki o belirsiz eşikte, hukukun güvenilir olmaktan uzaklaşmasını getirir. $\mathrm{Bu}$ durum da, mağdurların yasallığı ellerinde bulundurabilecekleri bir silah olarak görmekten ziyade, içinde durdukları bu bağlama direnebilmek için ellerinde bulunan her türlü ilişki ve duygulanıma son derece faydacı bir biçimde dönmesini getirir. Burada bahsedilen hukuki yapı, aile gibi geleneksel 
yapılar karşısında savaşan ve onların yerini güvenilirliği ile alarak vatandaşları özgür bireyler haline getiren bir hukuki yapı değil; vatandaşlarını sık sık öldürülebilen, ancak ölümleri siyaseten sayılmayan bedenlere dönüştürebilen bir hukuki yapıdır. Kısacası, olağan dışı yasallığın bu kadar olağan ve akışkan şekilde hayatımızda var olması, ailenin ve geleneksel addettiğimiz tüm yapıların hayatlarımızdaki merkeziyetlerinin devam edeceğini de düşündürtebilir.

Son olarak, anlatıların ortaya çıkardığı bir başka nokta da, Anayasa gibi yasallığın en genel özellikteki metinlerinin yanı sıra, aslında daha aşağıda var olan bir çok hareketi de eklemenin elzemliğidir; zira, bu hareketlerin yokluğunda sürdürülen Anayasa ya da genel hukuk tartışmalarının bir noktada tam da bu olağan ile olağan dışı arasındaki eşik alanı daha da perçinlemesi söz konusu olabilir. Her an yepyeni, herşeyi kapsayan ve herşeyi düzeltebilecek bir kural koyulacağı tasavvuru ${ }^{19}$, kural ile uygulamasının ve uygulayıcısının arasındaki mesafenin azalması halini normalleștirebilir. İster pozitif bir ümit ister negatif bir tutum ile olsun, dışarıdaki yasallığın kalıcı olmayabileceği ve de topyekun değiștirilmesi gerektiği duygusu, bir kez daha aile ve diğer geleneksel yapılardan başka hiçbir devlet kurumunun güvenilir ve kalıcı olmayacağı hissini uyandırıyor olabilir. şimdiden hiçbir kuralın kalıcı olamayabileceği hissinin beslenmesi ise, ileride kurulacak yeni bir geriye dönük adalet mekanizmasını yadırgamamıza ve hatta normal kabul etmemize sebep olabilir. Bunun da ötesinde, hukukun böyle topyekun değişmesini beklemek, aslında tam da ailevi ve cemaatsel tasavvurlarla desteklenmeyen hiçbir masumiyetin gerçek masumiyet olamayacağına bizi inandırıyor da olabilir. Bu durumun da, siyaset ile uğraşmanın kendisini olağan dışı addeden yeni muhafazakarlık ile uyumlu pasif bir duruş yaratmakta rol oynayabileceğini öngörmek mümkündür.

\section{BIBLIOGRAPHY}

Açan, İbrahim (1998) Burada Hukuk Geçmez, İstanbul, şubat Basım Yayım.

Agamben, Giorgio (1998) Homo Sacer: Sovereign Power and Bare Life, Stanford, Stanford University Press.

Aktan, İrfan (2006) Zehir ve Panzehir - Kurt Sorunu: Faşizmin şartı Kaç?, Ankara, Dipnot Yayınları.

Behramoğlu, Namık Kemal. [2013 (1998)] Bir Savcinin Anilari, Istanbul, Delta Yayıncılık.

Bourdieu, Pierre (1987) 'The Force of Law: Toward a Sociology of the Juridical Field', Hastings Law Journal 38, pp. 805-853.

Bourdieu, Pierre (1990) In Other Words: Essays Towards a Reflexive Sociology, Stanford, Stanford University Press.

Çelikkan, Murat (2004) ‘Darbeci, Ressammış!', Radikal, 11 Eylül, URL: http://www.radikal.com.tr/ haber.php?haberno=127636 
Certeau, Michel de (1984) The Practice of Everyday Life, Berkeley, Los Angeles and London, University of California Press.

Erdem, Zihni (2006) ‘Turk Adaleti Zamana Mağlup’, Radikal, 18 Mart, URL: http:// www.radikal.com.tr/haber.php?haberno $=181720$

(Imzasız) (2012) ‘Devrimin yapı işçisi', alinteri.net, 25 Ekim, URL: http://www.alinteri.org/? $\mathrm{p}=14654$.

(Imzasız) (2010) 'Yargıtay'da 20 bin dosya zamanaşımına uğradı', NTVMSNBC, 21 Aralık, URL: http://www.ntvmsnbc.com/id/25162655

(Imzasız) (2011) “'Yuzleşme” sırası İstanbul'da', Bianet, 29 Kasım, URL: http://wwww.bianet.org/ bianet/bilim/134378-yuzlesme-sirasi-istanbulda

İnsan Hakları Araştırma Derneği, İHAD (2009): Tanıklıklar - İnsan Hakları Belleğimiz, Ankara, Öztepe Matbaası.

İyigüngör, Vildan (2009) Medyada Tanıklı: Turkiye'de Askeri Darbeler, Istanbul, Beta Basım Yayın. Kuran, Mustafa (2003) Bir Avukatın Gül Bahçesi, Yazarın kendi yayını.

Kayasu, Sacit (2008) Onuncu Koyun Savcısl: 12 Eylul'un Son Mağduru, Istanbul, Metropol Yayınları.

Otacı, Cengiz (2007) 'Adli mekanizmayı hızlandırmak ve de yargının yukunu azaltmak şart', Radikal, 20 July, URL: http://www.radikal.com.tr/haber.php?haberno=227401.

Özer, Av. Mustafa (tarihsiz) 'Bambaşkaydı', URL: http://www.diyarbakirzindani.com/index.php? option=com_content\&task=view\&id=134\&Itemid=34

Parla, Taha (1993) Turkiye'de Anayasalar, Istanbul, İletişim Yayınları.

Povinelli, Elizabeth (2006) The Empire of Love: Toward a Theory of Intimacy, Genealogy, and Carnality, Durham and London, Duke University Press.

Sancar, Mithat (2008) “Devlet Aklı” Kıskacında Hukuk Devleti, Istanbul, İletişim Yayınları.

Tanör, Bülent (1986) İki Anayasa (1961-1982), Istanbul, Beta Basım Yayın.

Tanör, Bülent (2002[1992]) Osmanlı-Turk Anayasal Gelişmeleri, Istanbul, Yapı Kredi Yayınları.

T.C. Adalet Bakanlığı, Adli Sicil Genel Müdürlüğü, ‘Adalet İstatistikleri 2012', Yayın No 5, URL: http://www.adlisicil.adalet.gov.tr/ist_arsiv2.html

Turkiye Cumhuriyeti Anayasası, URL: http://www.tbmm.gov.tr/anayasa.htm

\section{NOTES}

1. Sayısı artan sıkıyönetim mahkemeleri ile ihtiyaç artarken, bir taraftan da varolan hakimlerin emekliye sevkedilmesi neticesinde yeni gelen hakimlerin yaşça daha genç olmaları durumu da ortaya çıkmıştır. Bu durumun da, yeni atanan genç hakimlerin diğer heyet üyelerinin ve özellikle de heyet başkanının etkisi altında kalma olasılıklarını artırmakta olduğu ileri sürülmüştür (Açan 1998: 280). Diğer yandan, sıkıyönetim mahkemelerine sivil hakim atama süreçlerinde hakimlerin siyasi görüşlerinin gözetildiği de bu atamalara ilişkin yapılan bir başka gözlemdir.

2. 1983 yılında Devlet Güvenlik Mahkemelerinin kurulması ile, sıkıyönetim mahkemelerinde görülen davalar bu yeni kurulan mahkemelere devredilir. 2004 yılında AB uyum süreci çerçevesinde lağvedilen Devlet Güvenlik Mahkemelerinin yerini ise genişletilmiş Ağır Ceza Mahkemeleri alır. 
3. Hatta bu duruma direnmek için avukatların üç yıldan fazla ceza alma yoluna giderek temyiz hakkı kazanmaya çalıştıkları da görülmektedir.

4. Bu çalışmada bu otobiyografilerin metinsel özelliklerine, bir diğer deyişle hukukçuların anlattıklarını nasıl anlattıklarına ve hatırladıklarını nasıl hatırladıklarına bakmak mümkün olmamıştır. Aynı şekilde, bu metinlerin yayım ve dağıtım stratejilerinin ne olduğu ve nasıl belirlendiği, nasıl bir izleyici kitlesi için yazıldıkları ve kimlere nerelerde dağıtıldıkları gibi konular da oldukça ilginç olmakla birlikte bu çalışma kapsamı dışında bırakılmışlardır.

5. Kavramın orjinali (juridical field) Pierre Bourdieu'ye aittir (Bourdieu 1987). Sayın İştar Gözaydın'a bu terimin eleştirisi için teşekkür ederim.

6. Bourdieu ise strateji terimini ayrım yapmadan, bir alandaki bütün hareketler için kullanır. $\mathrm{Bu}$ noktada, Bourdieu'nun asıl katkısı, stratejik olan hareketlerin yaratıc1/değiştirici ve statükoyu yeniden yapıcı taraflarının her zaman kısmi olarak gözlendiğinin altını çizmiş olmasıdır (Bourdieu 1990).

7. Doksan günden fazla sürecek tutukluluk durumunda ise hakimin izni alınıyordu.

*. Kaynağının bulunamaması sebebiyle bu sözün olduğu gibi aktarılmasına karar verilmiştir. [Editörün notu]

8. Tutuklunun davaya girmesine engel olan uygulamayı başka mecralar ve terimler üzerinden eleştirmek de avukatların kullandığı bir başka stratejidir. Örneğin, sözü geçen avukat eski bir levazım subayı olarak tek tip elbise uygulamasını eleştirir (Açan 1998: 198-205).

9. Ataman İnce davası. http://www.alinteri.org/?p=14654. Daha fazla bilgi için bkz. Açan (1998: 266-308).

10. Adalet Bakanlığı tarafından 2000-2004 yılları istatistiklerine dayanılarak yapılan açıklamada, her beş davadan birinin düştügüu, bu düşmelerin de \%95'inin zaman aşımından olduğu görülmektedir. http://www.radikal.com.tr/haber.php?haberno=181720, 'Türk Adaleti Zamana Mağlup', Radikal, 18 Mart 2006. Daha ileriki tarihli bir haberde ise zaman aşımından ötürü düşen dosyaların sayısı \%37 olarak verilmektedir. http://www.radikal.com.tr/haber.php? haberno=227401 'adli mekanizmayı hızlandırmak ve de yargının yükünü azaltmak şart', Radikal, 20 Temmuz 2007. 2010 yılı Adalet istatistiklerine göre, bu yıl itibarıyla ceza mahkemelerinde karara bağlanan toplam 3.327.504 dosyanın, 37.041'i zaman aşımı nedeniyle düşmüştür. Aynı veriler, gene 2010 yılı itibarıyla Yargıtay Ceza Genel Kurulu ve Ceza Dairelerinde bulunan toplam 573.576 davadan da \%36,5'inin sonuçlandırılarak karara bağlandığını, ve bu dosyaların da \%8,9'unun (toplam 18.633 dosya) zaman aşımına uğradığını ortaya koymaktadır. T.C. Adalet Bakanlığ1 Adli Sicil Genel Müdürlüğü, Adalet İstatistikleri 2012, Yayın No 5. http:// www.adlisicil.adalet.gov.tr/ist_arsiv2.html. Konuya ilişkin olarak Adalet Bakanı tarafından da basına bir açılklama yapılmıştır. Yargıtay'da 20 bin dosya zaman aşımına uğradı. NTVMSNBC, 21 Aralık 2010. http://www.ntvmsnbc.com/id/25162655.[S.K.]

11. Bu bağlamda hangi tarz davaların zaman aşımına uğradığı, kimlerin bu şekilde yargılanmaktan kurtulduğu ve hangi mahkemelerin ne gibi tarihlerde zaman aşımını yoğunlaştırdığı gibi sorular etrafında dönen zaman ve adalet usulü sorunsalı üzerine yapılacak ciddi bir araştırmanın bize çok şey gösterebileceği açıktır.

12. Madde 15: "Savaş, seferberlik, sıkıyönetim veya olağanüstü hallerde, milletlerarası hukuktan doğan yükümlülükler ihlâl edilmemek kaydıyla, durumun gerektirdiği ölçüde temel hak ve hürriyetlerin kullanılması kısmen veya tamamen durdurulabilir veya bunlar için Anayasada öngörülen güvencelere aykırı tedbirler alınabilir. (Değişik: 7/5/2004-5170/2 md.) Birinci fikrada belirlenen durumlarda da, savaş hukukuna uygun fiiller sonucu meydana gelen ölümler dışında, kişinin yaşama hakkına, maddî ve manevî varlığının bütünlüğüne dokunulamaz; kimse din, vicdan, düşünce ve kanaatlerini açıklamaya zorlanamaz ve bunlardan dolayı suçlanamaz; suç ve cezalar geçmişe yürütülemez; suçluluğu mahkeme kararı ile saptanıncaya kadar kimse suçlu sayılamaz". http://www.tbmm.gov.tr/anayasa.htm [S.K.] 
13. Bir hapishanede görüş sırasında çıkan bir tartışmada geçen bir olayı aynı zamanda albay olan avukat anlatıcı şöyle aktarır: "Birazdan bir yüzbaşı geldi. 'Siz bizim askerimize hakaret etmiş, tehditte bulunmuşsunuz' diye hesap soruyor benden. Yüzbaşıya, 'Sen şimdi yüzbaşısın değil mi?' dedim. 'Evet' diye yanıtladı. 'Ömrün varsa yarın birgün binbaşı olacaksın. Sonra yarbay,sonra albay, derken belki general de olursun. Ama sonunda bir gün emekli olacaksın, o üniformayı çıkaracaksın. O zaman bir onbaşı karşına çıkıp sana, küstahlık ederse bunu kabul edebilir misin?' diye sorunce şaşırdı. 'Ben' dedim, ‘Emekli albayım. Bunlar gibi yüzlercesi geçti benim önümden. şimdi kalkmış bana küstahlık yapıyor...'. Yüzbaşı anladı durumu, dönüp onbaşıyı azarladı.Ondan sonra ne zaman görüşe gitsem, o onbaşı beni görünce hemen yaltaklanmaya başlar, yardımcı olmaya çalışırdı" (Açan 1998: 138-139).

14. Özellikle sol görüşlü siyasi tutukluların durumlarında, bu kişilerin milli ve dinsel kültürün dışında addedilmeleri ve bu şekilde ötekileştirilmeleri -bir nebzeye kadar da kendilerini ötekileştirmeleri- nedeniyle, insanlık ve aile dışında başka bir cemaat kalmaz.

15. Burada tam da de Certeau'nun bahsettiği gibi, zaman değișkeninin kullanılmasıyla kurumsal stratejilerin nasıl etkisizleștirilmeye çalışıldığını görmek mümkündür.

16. Bazı otobiyografilerde, örneğin yüksek mahkeme üyelerinin anlatılarında olduğu gibi, 12 Eylül'e hafif bir kırgınlık da görülür; ancak, bu durum hukuk diliyle eleştirilir.

17. Bu maddelerin kendileri zaman içinde değişse de onların yerine yasalarda yeni maddeler yaratılır ve/veya uygulamada başka maddeler kullanılarak benzer etkiler yaratılır. Bir örnek için bkz. Çelikkan (2004).

18. Davanın devamı anlatılmaz.

19. Bir taraftan da, fiili olarak Anayasanın üçte birinden fazlası da aslında değiştirilmiştir.

\section{ABSTRACTS}

Bu çalışma, darbelerin dayandığı ve oluşturduğu adli alanı, gündelik hayattaki kuruluş, işleyiş ve kullanılış biçimleri üzerinden incelemektedir. 12 Eylül döneminin yasallı̆̆ı, bir demokratik süreç ve insan haklarının ihlali durumu olarak değil; tam da bu 'olağanüstü yasallık'ta kullanılan ve kurulan olağan dışı adli alanın olağanlaşması durumu üzerinden anlatılmaya çalışılacaktır. 12 Eylül darbesini yaşamış hukukçuların otobiyografileri derinlemesine incelenerek şu sorular üzerine düşünülecektir: 12 Eylül'ün yasallığı nasıl çalışıyordu? Bu yasallığı gündelik olarak kurmanın ve buna direnmenin yöntemleri neler idi? Bu olağan dışı dönem ile olağan hukuki dönem ve pratikler arasındaki bağlantı ve devamlılıklar ne gibi pratik ve tasavvurlar üzerinden kurulmaktadır? Bu çerçevede, metnin ilk bölümünde hukukçu otobiyografilerinde darbeye direnmenin koordinatlarını tartışılırken, ikinci bölümünde ise darbe yasallığına seyirci kalmanın nasıl anlatıldı̆̆ını araştırılacaktır. Bu iki noktayi bir arada tartışmaktaki amaç, aralarındaki karşıtlığı sorgulayabilmek ve bu yasallığa direnenler ile seyirci kalanların paylaştıkları tasavvur ve pratikleri anlayabilmektir. Bu çalışma bu yasallığı uygulayan, uygulayarak da aslında yeniden kuran, aktörlerin adli alanda birbirleri ile girdikleri ittifak ve rekabetleri anlamayı içeriyor. Bu sorgulama ışı̆̆ında, Türkiye'de olağanüstü yasallığın tarihsel devamlılığını mercek altına yatırmak hedeflenmiştir.

This study analyses the realm of law that military coups both create and rely upon, as well as the ways they are established, manufactured, and employed in daily life. It will attempt to 
understand the legality of the September 12 period of military rule not as part of a democratic process with a violation of human rights, but rather as the normalization of the field of extraordinary legality implemented during this 'state of exception.' Through an in-depth analysis of the autobiographies of jurists who lived through this era the following questions shall be considered: How did the legality of the September 12 regime work? What were the methods by which this approach to law was carried out on a day-to-day basis, and how were they resisted? On what practices and concepts were the continuities and connections between the legal state of exception and ordinary legal states based? Within this framework, this essay's first section will discuss the means of resistance to the coup described in the jurists' autobiographies, while the second will examine the ways in which some remained passive observers to the legality of the coup era. Through discussing these two points together, the aim is to question the differences between the two and better understand the ideas and practices shared by those who resist and those who observe passively. Through such an investigation, we seek to illuminate the historical continuities of the legal state of exception in Turkey.

\section{INDEX}

Keywords: 1980 military coup, state of emergency, extraordinary legality, jurists, resistance Mots-clés: 1980 darbesi, olağanüstü hal, olağanüstü yasallık, hukukçular, direniş 